Relations industrielles

Industrial Relations

\title{
Darek Sayer, Capitalism and Modernity: An Excursus on Marx and Weber
}

\section{Alexander J. Matejko}

Volume 46, numéro 2, 1991

URI : https://id.erudit.org/iderudit/050690ar

DOI : https://doi.org/10.7202/050690ar

Aller au sommaire du numéro

Éditeur(s)

Département des relations industrielles de l'Université Laval

ISSN

0034-379X (imprimé)

1703-8138 (numérique)

Découvrir la revue

Citer ce compte rendu

Matejko, A. J. (1991). Compte rendu de [Darek Sayer, Capitalism and Modernity: An Excursus on Marx and Weber]. Relations industrielles / Industrial Relations, 46(2), 491-493. https://doi.org/10.7202/050690ar

Tous droits réservés @ C Département des relations industrielles de l'Universite Laval, 1991
Ce document est protégé par la loi sur le droit d'auteur. L’utilisation des services d'Érudit (y compris la reproduction) est assujettie à sa politique d'utilisation que vous pouvez consulter en ligne.

https://apropos.erudit.org/fr/usagers/politique-dutilisation/ 
une deuxième où l'on retrouve, faisant l'objet de chacun des chapitres respectifs, les six phases d'une intervention facilitant le changement: l'entrée, le contrat, l'orientation (recadrage ou diagnostic), la planification des actions de changement, la réalisation et la terminaison (suivi). Enfin, une troisième partie traite plus spécifiquement de la relation de collaboration qui doit s'établir entre l'intervenant externe et le système-client (le groupe ou l'organisation qui est à l'origine d'une demande d'aide). Pour une lecture plus fructueuse de l'ouvrage, il serait utile de rappeler ici que la notion de consultation retenue et illustrée par les auteurs diffère sensiblement de la notion usuelle qui fait du consultant un conseiller-expert, c'est-à-dire une personne spécialisée dans un domaine de la gestion ou des sciences du comportement, se chargeant d'établir un diagnostic et de proposer des recommandations.

Il s'agit plutôt ici d'une notion de consultation qui s'inscrit dans une relation d'aide, dans une démarche de développement organisationnel ou de développement communautaire. En effet, ce type de consultation se distingue par au moins une caractéristique: celle d'engager les personnes concernées dans la conduite d'un diagnostic, l'élaboration des orientations à donner au changement. À ce sujet, nous croyons que les auteurs auraient dû, dès le point de départ, bien préciser à quelle enseigne ils se logeaient en faisant toutes les distinctions qui s'imposent entre la consultation conventionnelle ou d'expertise, le changement planifié, le développement organisationnel, le développement communautaire. Nous croyons que le rôle du consultant et les habiletés exigées diffèrent quelque peu au passage d'un milieu ou d'un type d'intervention à un autre.

Ces petites lacunes mises à part, il nous faut bien reconnaître que les auteurs ont su très bien allier la théorie à la pratique tout en fournissant un minimum d'instruments appropriés, sans ajouter à la complexité du sujet.

Laurent BÉLANGer

Université Laval

Capitalism and Modernity: An Excursus on Marx and Weber, by Derek SAYER, London and New York, Routledge, 1990, 10+164 p., ISBN 415-01728-9.

According to Webster, modernity means the state or quality of being modern. Sayer is interested in something else, namely how Marx and Weber understood the relationship between capitalism and modernity and what is the meaning of it for our present day understandings. When for the first of them capitalism was the demiurge of modern society, the second saw rationalization as the basic factor of progress. "Severance of the material means of a given human activity from its agents (which, just as for Marx, implies their isolation as solitary individuals) is the generic basis of all institutional rationalization. This is the key principle of that bureaucracy which for Weber pervades most arenas of modern life..." (p. 13). People more or less willingly accept the depersonalized order for the benefits which it offers to them; they are actually forced to subdue to the formalized rules and expectations because no alternative is available to them; the distinction of the "personal" from the "official" is fully implemented and this has several substantial consequences. According to Sayer, "the most significant of Weber's echoes of Marx lie in the contrast both draw between personalized and impersonal modes of administration and forms of power, and the bases of their legitimacy" (p. 141). The view of Marx is that modernity means the rule of individuals by abstractions whereas previously they were dependent on one another. 
Actually, dehumanization appears mainly in the manipulatory measures taken by people of power, entrepreneurs, bureaucrats, managers, mass media executives, statesmen, party leaders, military leaders, etc. in order to promote particularistic interests to the detriment of the weak and the dispossed, as well as against the public interest in general. Weber knew this very well so, it goes without saying, did Marx. Rational bureaucracy as an "iron cage" is not only difficult practically to implement even on the basis of modern technology but it also becomes counterproductive. The slavery of the assembly line appears as actually not only unhuman but also much doubtful from the cost/benefit perspective: the original investment is too high, it is difficult and expensive to introduce corrections later on, there is some waste involved, there is no room for flexibility, labour force is too much demotivated. Several sociologists unfortunately follow still Weber in the false identification of bureaucracy with rationality. There is plenty of evidence that rigidity and excessive formality do not fit into the modern reality of flexible market conditions in which the adaptability potential of individual enterprises is crucial not only for profit making but also for success.

The failure of Soviet communism originated at least partly from the much rigid bureaucracy evidently irrational because not able to tolerate individual or group entrepreneurship. Not only under state socialism but also under capitalism excessive "rationality" of a mechanical nature becomes self-defeating. The ideal arrangement appears to be more and more entrepreneurship based on minimal personnel and the contractual utilization of several other enterprises in order to limit the volume of necessary investment and to secure as much flexibility as possible. Under communism the millions of employees and huge resources were frozen in pseudo-rational central planning penetrating the whole economy to the detriment of effectiveness. It was actually the exercise in emptiness and now it becomes largely abandoned with Marx being blamed for his allegedly wrong suggestions (he never advocated the identification of socialism with the macro-bureaucratic set-up).

Under western capitalism and its emphasis of profit making many resources have been wasted, among them primarily the human resources: permanent unemployment especially among the young generation, reduction of employees to pseudo-machines, vulgarization of popular culture, promotion of egotism and lack of empathy, anomie.

Not Weber himself but several of his followers and admirers are guilty of creating the myth that the dehumanized bureaucracy is "objectively indispensable". This was somewhat valid as long as the rapidly industrializing western societies were effectively run by the traditional or self-imposed privileged groups which needed some public justification of their rule. Actually the growth of capitalism has been much irrational as it may be historically proved by tremendous waste, horrible wars, and other faults originating from greed, narrowmindness, bad treatment of people, and shortsight. It is pathetic that some intellectuals are now seriously taking the view that the present day systemic solutions are so perfect and permanent that we face "the end of history". Neither Marx nor Weber would be happy with such suggestion offensive to any power of historical imagination. It is worth to mention that paradoxically several of the intellectuals in the Soviet bloc have become so enthusiastic about the traditional capitalistic, free market model (not long ago considerable part of them enthusiastically supported stalinism) that they advocate the return to the past. They should be warned by pessimism of Weber himself who took into consideration the defeat of capitalism itself by the omnipotent bureaucracy, something actually happening now at least in some western countries, particularly in Scandinavia. The disenchantment of Weber with rationalization itself and "the impersonal deities of modernity" (p. 151) inspired him to see the only hope in personal integrity as the only effective way to limit damages originating from the soulless system and the unprecedented loneliness of the individuals facing the kafkesque castle. "Disembodies, the very forms of our sociality turn against us, and within them there is no place for human vaiues. 
The soulful corporation or the compassionate state are, by virtue of the very constitution of these social forms, contradictions in terms (...) The 'private life' of the 'abstract individual' becomes the pathetic sanctuary of humanity"' (p. 154).

The power of social imagination is much in demand in order to multiply the alternatives of social systems and to be put to trial for people's wellbeing and not against it. There are several forms which provide at least a partial hope to liberate societies from the "iron cage" of an omnipotent bureaucracy: the efforts to make modern states more "user friendly", quality of working life movement, various versions of sociotechnics, voluntary associations as problem solvers (sometimes they create more problems than they are able to solve), successful communes (primarily among them kibbutzes), flexible kinds of entrepreneurship (networking, matrix organization, etc.). All of them show that the pessimistic perspective which suggests the unavoidability of rigid and soulless bureaucracy is not fully justified. From that perspective, Marx was more imaginative than Weber but the latter represents more analytical depth.

We own Sayer an insighful comparison in that respect. His major contribution in this book is the analysis of modern subjectivity, specifically its divided character. He explains it in terms of the unavoidable discrepancy between personal experience and its public representation - most grotesque in communist systems, but hardly confined to them. The "iron cage" is actually never complete, and the bureaucratic establishment is always precarious. More simply, modern domination is more or less the domination of lies, as Havel said.

Alexander J. Matejko

University of Alberta

\title{
L'ENSEIGNEMENT ET LA RECHERCHE EN RELATIONS INDUSTRIELLES TEACHING AND RESEARCH IN INDUSTRIAL RELATIONS
}

\author{
Rapport du 27e Congrès de l'Association canadienne \\ des relations industrielles/Proceedings of the 27th Conference of the Canadian \\ Industrial Relations Association
}

Édité par/Edited by

Allen Ponak

ACRI/CIRA

Département des relations industrielles

Université Laval, Québec, Qc

Canada, G1K 7P4 